CARPATHIAN JOURNAL OF FOOD SCIENCE AND TECHNOLOGY

journal homepage: http://chimie-biologie.ubm.ro/carpathian_journal/index.html

\title{
FIRST REPORT OF NUTRITIONAL VALUE AND CONSUMER ACCEPTABILITY OF 'KATI' PRODUCED FROM SORGHUM USING LACTIC ACID BACTERIA AS STARTER CULTURES
}

\author{
Emmanuel Olabanji Afolabi ${ }^{1}$, Clement Olusola Ogidi ${ }^{2}{ }^{凶}$ and Bamidele Juliet Akinyele ${ }^{1}$
}

${ }^{1}$ Department of Microbiology, The Federal University of Technology, PMB 704, Akure, Nigeria

${ }^{2}$ Biotechnology Unit, Department of Biological Sciences, Kings University, PMB 555, Odeomu, Nigeria

$\triangle_{\text {clementogidi@yahoo.com }}$

https://doi.org/10.34302/crpjfst/2020.12.3.13

Article history:

Received:

Accepted:

10 June 2019

18 June 2020

Keywords:

Cereal foods:

Lactic acid bacteria

Nigeria

'Kati'

\section{ABSTRACT}

Most fermented cereal-based foods are source of nutrients and energy for human being. Hence, a large number of fermented cereal products are consumed daily in Africa. 'Kati', an indigenous food to Akoko in Ondo State, Nigeria was produced using different Lactic acid bacteria (LAB) as starter cultures. Nutrient contents and sensory evaluation of 'Kati' produced with different LAB as starter culture were assessed. Saccharomyces cerevisiae have the highest occurrence $(20.8 \%)$ during the steeping of sorghum. Lactobacillus plantarum was most predominant bacterium in the fermented slurry with the value of $19.5 \%$. 'Kati' produced with Lactobacillus spp. have moisture (64.0 to $67.23 \%$ ), ash (0.39 to $0.47 \%$ ), crude fibre (1.05 to $2.31 \%$ ), protein (2.02 to $5.15 \%$ ) and carbohydrates ( 24.12 to $27.35 \%)$ contents. The fermented food has minimal value of phytates $(0.64-0.77 \mathrm{mg} / 100 \mathrm{~g})$, phenols $(11.47-14.75 \mathrm{mg} / 100 \mathrm{~g})$, tannins $(0.40-0.51 \mathrm{mg} / 100 \mathrm{~g})$, and oxalates $(0.11-0.18 \mathrm{mg} / 100 \mathrm{~g})$. 'Kati' produced with each Lactobacillus spp. were preferred to panellists in terms of general acceptability. LAB generally regarded as safe (GRAS), can be used as starter culture to improve nutritional contents and organoleptic property of traditional foods in order to gain wide acceptance by consumers.

\section{Introduction}

Sorghum, millet, maize, wheat, rice, barley, rye and oat are grains (cereals), mostly considered as one of the important food sources. They are widely cultivated and available in greater quantities since they are the major nutrients for human (Lafiandra et al., 2014). Although, bioactive compounds in cereals played significant roles but cereals are still found deficient in some basic components such as essential amino acids and vitamins (Sandhu et al., 2017). Despite the nutritional deficiency in cereals, its components remain better substrate of fermented foods (Achi and Asamudo, 2019). Several indigenous fermented foods and drinks are produced from cereals by simple biotechnological techniques to alleviate food insecurity (Blandino et al., 2003).

Often time, the desirable biochemical changes and significant modification of cereals were achieved by the presence of microorganisms and appropriate enzymes involved during fermentation (Campbell-Platt, 1994), which make the final product more nutritious, digestible, tastier and safer for consumers. Fermented products have a longer shelf life than their original substrate, hence, fermentation is advantageous in food preservation (Egwim et al., 2013). Besides prolonged shelf life and digestibility of fermented foods, fermentation improves nutrient level in food by enhancing bioavailability of minerals, eliminating the risk 
of antinutrients, improving the food safety by inhibiting microbial pathogens (Assohoun et al., 2013). Fermented foods are widely accepted as a result of expanding scientific evidences pointing to their beneficial effects on human health.

Africa are known to have an age-old history of traditionally fermented foods rich in probiotics (Egwim et al., 2013). Unfortunately, some of these fermented foods are not widely known or accepted due to different methods of production with chance inoculation, use of rudimentary equipment, and consumption within the rural community. 'Kati' is one of the understudied indigenous foods that is consumed in Akoko community, Ondo State, Southwestern Nigeria. Research documentations have been made on many fermented cereal products from sorghum such as: 'Gowè', 'Kunun-zaki' and 'Ogi-baba' (Oguntoyinbo and Narbad, 2012), maize products: 'Mawè', 'Ogi' and 'Koko' (Adimpong et al. 2012), rice products: 'Sake', 'Dosa', 'Idli', 'Miso' and 'Dhokla' (Kumari et al., 2015). The fermented foods are produced through traditional fermentation with mixed cultures of Lactic Acid Bacteria (LAB). Some LAB have been used as starter cultures in laboratory trials due to their higher lactic acid production, rapid acidification, superior shelf life quality attributed to foods as well as improving organoleptic properties of the final products. Hence, a greater degree of controlled fermentation processes has been achieved with the use of starter cultures to produce some traditional foods (Adesulu and Awojobi, 2014). There is a need to research on local foods that are consumed since ages by identifying and revealing the best starter cultures associated with the food production. Therefore, this study aimed to produce 'Kati' from sorghum (white or and red) using different LAB as starter cultures. The nutrient contents and sensory evaluation of produced 'Kati' were assessed.

\section{Materials and methods collection of samples}

White and red sorghum used for this study were purchased from King's market, Akure,
Nigeria. The samples were collected in a locked bag and transported to the laboratory for further analysis.

\subsection{Preparation of 'Kati'}

Each grain $(500 \mathrm{~g})$ of white, red and mixture (1:1) was weighed into different sterile plastic bowl containing water. The grains were thoroughly washed for two consecutive times. Thereafter, each group of grains was steeped into different sterile bowls containing 2,500 ml of water for $72 \mathrm{~h}$ and well covered. Thereafter, samples were washed with sterile water and wet milled using a clean grinder. The milled samples of white, red or mixture was fermented for $24 \mathrm{~h}$ and thereafter, molded in wrapped leaves: Ficus carica and Thaumatococcus daniellii. The samples were cooked in aluminum pot under smoldering fire for 45-50 min.

\subsection{Enumeration and isolation of microorganisms}

Microbial evaluation of steep water and fermented milled sorghum (red, white and mixture) were carried out using the method of Cappuccino and Sherman (1999). Briefly, 10 $\mathrm{ml}$ from steeping of sorghum or $10 \mathrm{~g}$ of milled sorghum after fermentation was transferred into $90 \mathrm{ml}$ of sterile peptone water. Thereafter, 10fold dilutions were prepared and $1.0 \mathrm{ml}$ was dispensed from the dilution onto Petri dish using pour plate method. Cool nutrient agar, de Man Rogosa and Sharpe agar (MRS) and Sabouraud Dextrose Agar (SDA) were introduced for the cultivation of bacteria and fungi. The plates were incubated at $30^{\circ} \mathrm{C}$ for $24 \mathrm{~h}$ and $25^{\circ} \mathrm{C}$ for 48 $\mathrm{h}$ for the growth of bacteria and fungi. The plates containing MRS was incubated under anaerobic condition. Gram's staining and some biochemical tests such as catalase, oxidase, coagulase, motility, methyl red, Vogesproskauer, starch hydrolysis and sugars fermentation were carried out. The biochemical results were compared to Bergey's Manual of Systematic Bacteriology (Krieg et al., 2010). The fungi isolates were identified using method of Samson et al. (2010). 
2.3.Determination of temperature, $\mathrm{pH}$ and total titratable acidity of fermented slurry

The temperature of the sample was determined with thermometer (HANNA HI 9828). $\mathrm{pH}$ was determined at intervals of $48 \mathrm{~h}$ using Jenway $\mathrm{pH}$ meter. The total titratable acid (TTA) was determined using the method of AOAC (1990), briefly, $20 \mathrm{ml}$ of milled sorghum was diluted with distilled water $(20 \mathrm{ml})$ and titrated with $0.1 \mathrm{M} \mathrm{NaOH}$ into an end point of permanent pink colour using phenolphthalein as indicator.

\subsection{Sensory evaluation of produced Kati}

The sensory evaluation of 'Kati' produced from white, red and mixed sorghum was initially determined. Sensory evaluation was conducted as described by Meilgaard et al. (2007) for taste, colour, texture, aroma and overall acceptability by 10 -member panelists selected from public and academic environment based on familiarity and interest on 'Kati'. The parameters were rated on a 9 points hedonic scale. Kati from mixture of white and red sorghum was highly accepted after sensory evaluation and was selected for further studies.

Having known the best substrate for 'Kati' production, it was re-produced using different LAB isolated from fermented slurry of mixed sorghum (white and red). This is to reveal the best starter culture for the production of 'Kati'. The ready-to-eat 'Kati' was purchased from Arigidi Akoko and used as control in this experiment.

\subsection{Proximate and mineral analysis of 'Kati' produced with different starter cultures}

The proximate analysis was carried out using method of AOAC (1990). The moisture content was estimated by drying method. Ash content was determined putting $5 \mathrm{~g}$ in crucible and then placed in muffle furnace at $550{ }^{\circ} \mathrm{C}$ for $4 \mathrm{~h}$. The fat content was determined using the Soxhlet type of direct solvent extraction method. The thimble was removed, placed in a hot-air oven and dried at $105^{\circ} \mathrm{C}$ for $1 \mathrm{~h}$. The thimble was placed in a desiccator and allowed to cool. Crude fibre was determined by defatting $2 \mathrm{~g}$ of sample.
Briefly, sulphuric acid (200 $\mathrm{ml}$ of $1.25 \%$ ) was added and the content was boiled for $30 \mathrm{~min}$. The sample was filtered under vacuum followed by repeated washing with distilled water. The sample was later returned to the flask with the addition of $200 \mathrm{ml}$ of $1.25 \% \mathrm{NaOH}$. This was boiled for $30 \mathrm{~min}$ and filtered. The sample was thoroughly washed with distilled water, followed by $10 \% \mathrm{HCl}$ and further washing with distilled water to free the sample of any adhering acid. The sample was further treated with $10 \mathrm{ml}$ of petroleum ether and $10 \mathrm{ml}$ of ethanol. The sample was scooped into an empty crucible and placed in a hot-air oven at $105^{\circ} \mathrm{C}$ for $1 \mathrm{~h}$. Protein content of sample was determined by microKjeldahl method. The percentage nitrogen content in each sample was calculated and multiplied by 6.25 to get the percentage protein content. The total carbohydrate content of each sample was estimated by difference.

$\%$ carbohydrates $=100-(\%$ moisture $+\%$ ash + $\%$ fat $+\%$ protein $+\%$ crude fibre) .

The mineral; potassium (K), sodium (Na), calcium $(\mathrm{Ca})$ and magnesium $(\mathrm{Mg})$ contents in 'Kati' were analyzed from ash samples using atomic absorption spectrometer. Phenol and tannin content in 'Kati' were determined using methods stated by Makkar and Goodchild (1996). The quantity of oxalates and phytate in 'Kati' was determined using the methods of Krishna and Ranahan (1980).

\section{Results and discussions}

The bacterial and fungal count during steeping of sorghum and its fermented slurry was recorded in Table 1 . The mixed samples have the highest count in all the days except the fungal count at 0 hour (h), in which the white and mixed sorghum have the same count. It was observed that both bacterial and fungal count increased steadily from 0 to $72 \mathrm{~h}$ but higher microbial count was observed in mixed sorghum than red or white sorghum. This could be as a result of time needed for the organisms to adapt to the new environment. Findings of Ogodo $e t$ al. (2019) attributed stabilization of microorganisms to utilization of available nutrient in medium during fermentation. The 
steady increase after initial hour could be as a result of microbial build up due to nondisturbance of the water during steeping. It was reported by Van-Nierop et al. (2006) that population of microorganisms increased during steeping and conditions (temperatures, moisture and airflow) enable grain germination as well as microbial growth. The decrease in bacterial and fungal count after $48 \mathrm{~h}$ could be as a result of depletion of nutrient and increase in acid content of the medium which may affect non-lactic bacteria (Ogodo et al., 2019).

Table 2 shows percentage occurrence of microorganisms isolated during steeping of sorghum. Saccharomyces cerevisiae possessed the highest occurrence (20.8\%), while Candida albicans and Staphylococcus aureus have the same least value of $3.0 \%$. Saccharomyces cerevisiae, Corynebacterium spp. and Lactobacillus spp. were mainly present at 24- 72 $\mathrm{h}$, which may due to limited oxygen availability during steeping. Aeration during steeping enhances proliferation, resulting in a coat of bacteria, yeasts and fungal spores on steeped grains (Justé et al., 2011). Increase in acidity of the steeping water favours LAB and contributed to continuous decreasing of other bacteria and fungi (Okeke et al., 2015).

Saccharomyces cerevisiae (20.8\%) was the most dominant microbe amongst other microbes isolated during the stepping process. Gobbetti et al. (1994) and Steinkraus (1996) proposed that LAB create an acidic environment (lower $\mathrm{pH}$ ) conducive to yeast proliferation, while the yeasts provide vitamins and other growth factors such as amino acids for the lactic acid bacteria. Ali and Mustafa (2009) reported that, the simultaneous increase in numbers of both LAB and yeasts could be attributed to their symbiotic association in fermented sorghum dough. The isolation of other microorganisms, which did not have definite role could either occur as contaminants form stepping water or body contact, Holzapfel (1997) revealed that all microbial genera are not of equal importance in fermentation therefore, candidate isolates for starter culture development have to be evaluated for their contribution during fermentation.
Table 3 shows percentage occurrence of LAB isolated from fermented slurry of sorghum. Lactobacillus plantarum was most predominant in the fermented slurry of sorghum with the value of $19.5 \%$, while Lactobacillus jensenii had the least occurrence of $9.8 \%$. In this study, LAB predominantly isolated from traditionally fermented 'Kati' were Lactobacillus casei, Lactobacillus salivarius, Lactobacillus jensenii, Lactobacillus cellobiosus, Lactobacillus plantarum, Lactobacillus delbrueckii, and Lactobacillus fermentum. Most of LAB isolated from the fermented sorghum are similar to what isolated from other fermented foods (Abegaz, 2007; Chelule et al., 2010 and Mukisa et al., 2016). Similarly, members of lactobacilli can be detected in a variety of habitat include fermented foods and dairy products (Admassie, 2018). LAB survive in acidic environment during fermentation. Its prevalence could also be as a result of its fast and predominant growth under fermentation conditions (Soro-Yao et al., 2014). LAB have found in many traditional foods to improve organoleptic properties and shelf life. The functional properties displayed by LAB can be attributed to their ability to produce heatstable antimicrobial compounds or ribosomally synthesized antimicrobial peptides called bacteriocins, which prevent the growth of other microbes (De Vuyst and Vandamme, 1994). L. plantarum was the predominant among the isolated LAB. This could be as a result of its higher acid tolerance. LAB obtain energy through substrate-level phosphorylation following two metabolic pathways for hexose fermentation (homofermentative and heterofermentative) and thus, characterized by production of lactic acid as major end metabolic product (Mora-Villalobos et al., 2020).

The elimination of some microorganisms, which present during steeping could be as a biofunctionality displayed by the LAB. The bacteria produce lactic acid, diacetyl, acetaldehyde and hydrogen peroxide as fermentation end-products. These products possess eliminate or retard the growth of many spoilage microorganisms, which enables them to 
be used as bio-preservatives in foods, feeds and beverages (Justé et al., 2011).

Table 4 shows the physicochemical properties of milled sorghum during fermentation. The $\mathrm{pH}$ of white sorghum (5.94.5); red sorghum (5.0-4.2) and mixed sorghum (5.3-4.4) decreased as the fermentation progressed from $0-48 \mathrm{~h}$, while TTA increased from 2.2 to 3.5 . The decrease in $\mathrm{pH}$ is suitable for lactic acid bacteria to grow and remain viable within a medium containing higher amount of lactic acid. Obadina et al. (2013) and Omemu et al. (2018) reported the decreased in $\mathrm{pH}$ and increase in TTA during fermentation process of traditionally fermented food products. Table 5 reveals the consumer acceptability of 'Kati' from white, red and mixed sorghum. 'Kati' from mixed white and red sorghum was most preferred with overall acceptance of 6.88 . Fermented foods and beverages are widely accepted by consumers due to their enhanced nutritional content, digestibility, microbial stability and detoxification (Anal, 2019).

The proximate composition of produced 'Kati' using different starter cultures was recorded in Table 6. The moisture, ash, crude fibre, protein and carbohydrates contents (\%) ranged from 64.0 to $67.23,0.39$ to $0.47,1.05$ to $2.31,2.02$ to 5.15 and 24.12 to 27.35 , respectively. The higher moisture content could be attributed to the steeping of sorghum in water for period of time and addition of water during cooking. The low content of ash could be due to complete utilization of minerals by microorganisms involved during fermentation for their metabolism. The result of the antinutrient composition of 'Kati' produced using different starter cultures was recorded in Table 8. Sorghum has significant amounts of phytate. Phytate has been recognized as anti-nutrient factor that reduces bioavailability some macroand micro-elements (Soro-Yao et al., 2014).
'Kati' produced with Lactobacillus spp. have minimal value of phytates $(0.64-0.77 \mathrm{mg} / 100 \mathrm{~g})$, phenols (11.47-14.75 mg/100g), tannins (0.40$051 \mathrm{mg} / 100 \mathrm{~g})$, oxalates $(0.11-0.18 \mathrm{mg} / 100 \mathrm{~g})$. This suggests that Lactobacillus spp. could produce enzymes, which help to degrade the anti-nutrients during fermentation (Adeyemo and Onilude, 2013). LAB remove some nonnutrients component and synthesize vitamins, bioactive peptides, conjugated linoleic, exopolysaccharides, bacteriocins, sphingolipids that are known for health benefits (Şanlier et al., 2019).

The sensory evaluation of quality and acceptability of 'Kati' (Table 7) indicated that, samples produced with different LAB were well accepted for consumption. Sensory evaluation remains a mechanism to reported acceptance and consumption of foods (Yang and Lee, 2019). It has been realized that, sensory evaluation could contribute pertinent, valuable information related to marketing consequences and simultaneously provide direct actionable information (Delwiche, 2009). Fermentation makes food more palatable by enhancing its aroma and flavour with better taste. Fermented foods are more accepted by consumers than unfermented one due to their organoleptic properties (Blandino et al., 2003).

Findings of Hasan et al. (2014) and Dimidi et al. (2019) suggested that viable LAB such as Lactobacillus bulgaricus, Lactobacillus acidophilus, Streptococcus thermophilus and Bifidobacterium bifidum interfere with gut colonization to prevent proliferation of food borne pathogens, thereby preventing manifestation various gastrointestinal infections. 
Table 1. Bacterial and fungal count from steeped water and fermented slurry of sorghum

\begin{tabular}{|c|c|c|c|c|c|c|}
\hline \multicolumn{4}{|c|}{ Bacteria $\left(\right.$ cfu $\left.\mathrm{mL}^{-1}\right)$} & \multicolumn{3}{|c|}{ Fungi (sfu mL $\mathbf{m}^{-1}$ ) } \\
\hline \multicolumn{7}{|c|}{ Steeped water } \\
\hline & White & Red & Mixed & White & Red & Mixed \\
\hline 0 & $1.8 \times 10^{6}$ & $1.7 \times 10^{6}$ & $2.0 \times 10^{6}$ & $4.0 \times 10^{3}$ & $0.3 \times 10^{4}$ & $4.0 \times 10^{3}$ \\
\hline 24 & $3.2 \times 10^{6}$ & $2.8 \times 10^{6}$ & $3.8 \times 10^{6}$ & $2.5 \times 10^{4}$ & $2.3 \times 10^{4}$ & $2.8 \times 10^{4}$ \\
\hline 48 & $4.0 \times 10^{5}$ & $2.0 \times 10^{5}$ & $6.0 \times 10^{5}$ & $3.5 \times 10^{4}$ & $3.0 \times 10^{4}$ & $4.0 \times 10^{3}$ \\
\hline 72 & $6.0 \times 10^{5}$ & $4.0 \times 10^{5}$ & $8.0 \times 10^{5}$ & $4.0 \times 10^{3}$ & $3.0 \times 10^{3}$ & $4.5 \times 10^{3}$ \\
\hline \multicolumn{7}{|c|}{ Fermented slurry of sorghum } \\
\hline 0 & $1.0 \times 10^{3}$ & $1.0 \times 10^{3}$ & $2.0 \times 10^{3}$ & $1.0 \times 10^{3}$ & $1.0 \times 10^{3}$ & $2.0 \times 10^{3}$ \\
\hline 24 & $1.2 \times 10^{3}$ & $3.0 \times 10^{3}$ & $3.5 \times 10^{3}$ & $1.5 \times 10^{3}$ & $2.0 \times 10^{3}$ & $2.5 \times 10^{3}$ \\
\hline 48 & $2.0 \times 10^{3}$ & $3.5 \times 10^{3}$ & $3.5 \times 10^{3}$ & $3.0 \times 10^{3}$ & $3.0 \times 10^{3}$ & $3.5 \times 10^{3}$ \\
\hline
\end{tabular}

Table 2. Occurrence of microorganisms during steeping of sorghum for 'Kati' production

\begin{tabular}{|c|c|c|c|c|c|c|c|c|c|c|c|c|c|c|}
\hline \multirow[t]{2}{*}{ Isolates } & \multicolumn{4}{|c|}{ White } & \multicolumn{4}{|c|}{ Red } & \multicolumn{4}{|c|}{ White and red } & \multirow{2}{*}{$\begin{array}{l}\text { Number } \\
\text { of } \\
\text { isolates }\end{array}$} & \multirow[t]{2}{*}{ \% Occurrence } \\
\hline & 0 & 24 & 48 & 72 & 0 & 24 & 48 & 72 & 0 & 24 & 48 & 72 & & \\
\hline $\begin{array}{l}\text { Saccharomyces } \\
\text { cerevisiae }\end{array}$ & - & + & + & + & - & + & + & + & - & + & + & + & 14 & 20.8 \\
\hline Corynebacterium spp & - & + & + & + & - & - & - & + & - & + & + & + & 12 & 18.0 \\
\hline Lactobacillus spp. & - & + & + & + & - & + & + & + & - & + & + & + & 9 & 13.4 \\
\hline $\begin{array}{l}\text { Clostridium } \\
\text { bifermentans }\end{array}$ & - & - & - & - & + & + & - & - & + & + & - & - & 9 & 13.4 \\
\hline Aspergillus niger & + & - & - & - & + & + & - & - & + & - & - & - & 6 & 9.0 \\
\hline Aspergillus flavus & + & - & - & - & + & - & - & - & + & - & - & - & 6 & 9.0 \\
\hline Fusarium oxysporium & + & + & - & - & - & - & - & - & + & - & - & - & 4 & 6.0 \\
\hline Muсоr тисеdo & + & - & - & - & + & - & - & - & - & - & - & - & 3 & 4.4 \\
\hline Candida albicans & - & - & - & - & - & - & - & - & + & - & - & - & 2 & 3.0 \\
\hline Staphylococcus aureus & + & - & - & - & - & - & - & - & - & - & - & - & 2 & 3.0 \\
\hline
\end{tabular}

-: absent, +: present 
Table 3. Occurrence of LAB in milled sorghum at different hour(s) of fermentation

\begin{tabular}{|c|c|c|c|c|c|c|c|c|c|c|c|}
\hline \multirow[t]{2}{*}{ *Isolates } & \multicolumn{3}{|c|}{ White } & \multicolumn{3}{|c|}{ Red } & \multicolumn{3}{|c|}{ White and red } & \multirow{2}{*}{$\begin{array}{l}\text { Number of } \\
\text { isolates }\end{array}$} & \multirow{2}{*}{$\begin{array}{c}\% \\
\text { Occurrence }\end{array}$} \\
\hline & 0 & 24 & 48 & 0 & 24 & 48 & 0 & 24 & 48 & & \\
\hline Lactobacillus plantarum & + & + & + & + & + & + & + & + & + & 16 & 19.5 \\
\hline Lactobacillus fermentum & - & + & + & + & + & + & + & + & + & 14 & 17.1 \\
\hline Lactobacillus delbrueckii & - & + & + & - & + & + & - & + & + & 12 & 14.6 \\
\hline Lactobacillus casei & - & + & + & - & + & + & - & + & + & 12 & 14.6 \\
\hline Lactobacillus cellobiosus & + & + & + & - & + & + & + & + & + & 11 & 13.4 \\
\hline Lactobacillus salivarius & - & - & + & - & + & + & - & + & + & 9 & 11.0 \\
\hline Lactobacillus jensenii & - & + & + & - & + & + & - & + & + & 8 & 9.8 \\
\hline
\end{tabular}

-: absent, +: present, *each of LAB was used as starter culture to produce 'Kati' with mixed sorghum

Table 4. Physicochemical parameters of milled sorghum during fermentation at different hour(s)

\begin{tabular}{|l|l|l|l|l|l|l|l|l|l|}
\hline \multicolumn{4}{|c|}{ White sorghum } & \multicolumn{3}{c|}{ Red sorghum } & \multicolumn{3}{c|}{ Mixed sorghum } \\
\hline Time (h) & Temp $\left({ }^{\circ} \mathrm{C}\right)$ & $\mathrm{pH}$ & TTA $(\%)$ & Temp $\left({ }^{\circ} \mathrm{C}\right)$ & $\mathrm{pH}$ & TTA $(\%)$ & Temp $\left({ }^{\circ} \mathrm{C}\right)$ & $\mathrm{pH}$ & TTA $(\%)$ \\
\hline 0 & 26 & 5.9 & $2.2 \pm 0.0$ & 25 & 5.1 & $2.0 \pm 0.0$ & 25 & 5.3 & $1.7 \pm 0.0$ \\
\hline 24 & 29 & 4.8 & $3.0 \pm 0.3$ & 30 & 4.7 & $2.4 \pm 0.3$ & 30 & 4.6 & $1.9 \pm 0.0$ \\
\hline 48 & 30 & 4.5 & $3.5 \pm 0.5$ & 31 & 4.2 & $2.5 \pm 0.4$ & 32 & 4.4 & $2.0 \pm 0.0$ \\
\hline
\end{tabular}

Table 5. Sensory evaluation of 'Kati' produced from white, red and mixed sorghum

\begin{tabular}{|l|l|l|l|}
\hline Sensory properties & White & Red & White and red \\
\hline Taste & $5.70^{\mathrm{b}} \pm 0.85$ & $5.60^{\mathrm{b}} \pm 0.90$ & $6.65^{\mathrm{a}} \pm 2.00$ \\
\hline Colour & $6.00^{\mathrm{b}} \pm 0.76$ & $5.60^{\mathrm{c}} \pm 0.66$ & $6.98^{\mathrm{a}} \pm 0.76$ \\
\hline Texture & $6.60^{\mathrm{b}} \pm 2.00$ & $5.31^{\mathrm{c}} \pm 2.00$ & $7.00^{\mathrm{a}} \pm 0.89$ \\
\hline Aroma & $5.00^{\mathrm{c}} \pm 0.76$ & $5.50^{\mathrm{b}} \pm 0.90$ & $6.90^{\mathrm{a}} \pm 1.20$ \\
\hline Overall acceptance & $5.83^{\mathrm{b}} \pm 0.68$ & $5.50^{\mathrm{b}} \pm 0.71$ & $6.88^{\mathrm{a}} \pm 2.00$ \\
\hline
\end{tabular}

Values with the same superscript in a row are not significantly different at $P \geq 0.05$ 
Table 6. Proximate $(\%)$, mineral $(\mu \mathrm{g} / \mathrm{g})$ and anti-nutrient $(\mathrm{mg} / 100 \mathrm{~g})$ of 'Kati' produced from mixture of white and red sorghum with LAB starter cultures

\begin{tabular}{|c|c|c|c|c|c|c|c|c|}
\hline Parameter & $\mathbf{1}$ & 2 & 3 & 4 & 5 & 6 & 7 & 8 \\
\hline Moisture & $66.59 \pm 0.07$ & $64.00 \pm 0.77$ & $66.37 \pm 0.06$ & $67.23 \pm 0.13$ & $67.16 \pm 0.14$ & $66.58 \pm 0.06$ & $67.14 \pm 0.16$ & $65.02 \pm 0.06$ \\
\hline Ash & $0.47 \pm 0.01$ & $0.41 \pm 0.06$ & $0.45 \pm 0.03$ & $0.43 \pm 0.05$ & $0.42 \pm 0.01$ & $0.40 \pm 0.03$ & $0.39 \pm 0.01$ & $0.41 \pm 0.02$ \\
\hline Fat & $1.95 \pm 0.05$ & $2.73 \pm 0.02$ & $1.73 \pm 0.03$ & $2.53 \pm 0.05$ & $1.72 \pm 0.06$ & $1.34 \pm 0.04$ & $2.72 \pm 0.07$ & $4.10 \pm 0.77$ \\
\hline Crude fibre & $1.72 \pm 0.05$ & $1.86 \pm 0.08$ & $2.31 \pm 0.05$ & $1.72 \pm 0.03$ & $1.39 \pm 0.07$ & $1.05 \pm 0.06$ & $1.47 \pm 0.07$ & $1.05 \pm 0.01$ \\
\hline Protein & $5.15 \pm 0.02$ & $5.05 \pm 0.04$ & $2.09 \pm 0.03$ & $3.48 \pm 0.02$ & $2.02 \pm 0.06$ & $3.28 \pm 0.06$ & $2.07 \pm 0.06$ & $2.68 \pm 0.84$ \\
\hline Carbohydrates & $24.12 \pm 0.25$ & $25.95 \pm 0.03$ & $27.05 \pm 0.73$ & $24.61 \pm 0.06$ & $27.29 \pm 0.05$ & $27.35 \pm 0.01$ & $26.21 \pm 0.08$ & $26.74 \pm 0.02$ \\
\hline $\mathrm{Na}$ & $15.40 \pm 0.01$ & $14.80 \pm 0.01$ & $15.00 \pm 0.02$ & $14.20 \pm 0.04$ & $14.60 \pm 0.02$ & $19.00 \pm 0.02$ & $17.10 \pm 0.01$ & $21.03 \pm 0.01$ \\
\hline $\mathrm{K}$ & $85.50 \pm 0.02$ & $93.00 \pm 0.02$ & $92.06 \pm 0.02$ & $94.20 \pm 0.02$ & $89.40 \pm 0.02$ & $94.90 \pm 0.01$ & $83.00 \pm 0.02$ & $97.02 \pm 0.22$ \\
\hline $\mathrm{Ca}$ & $30.00 \pm 0.02$ & $21.05 \pm 0.01$ & $22.20 \pm 0.00$ & $18.04 \pm 0.02$ & $26.05 \pm 0.01$ & $20.02 \pm 0.00$ & $17.50 \pm 0.02$ & $36.04 \pm 0.01$ \\
\hline $\mathrm{Mg}$ & $30.03 \pm 0.02$ & $45.00 \pm 0.02$ & $38.04 \pm 0.02$ & $47.03 \pm 0.00$ & $42.02 \pm 0.01$ & $32.00 \pm 0.00$ & $48.50 \pm 0.00$ & $52.22 \pm 0.02$ \\
\hline Phytates & $0.73 \pm 0.00$ & $0.74 \pm 0.08$ & $0.64 \pm 0.04$ & $0.67 \pm 0.08$ & $0.78 \pm 0.04$ & $0.94 \pm 0.04$ & $0.77 \pm 0.04$ & $0.73 \pm 0.01$ \\
\hline Phenols & $11.47 \pm 0.05$ & $12.15 \pm 0.01$ & $12.47 \pm 0.02$ & $12.28 \pm 0.06$ & $11.89 \pm 0.08$ & $12.35 \pm 0.06$ & $12.70 \pm 0.01$ & $14.75+0.02$ \\
\hline Tannins & $0.46 \pm 0.01$ & $0.49 \pm 0.01$ & $0.48 \pm 0.02$ & $0.50 \pm 0.03$ & $0.48 \pm 0.02$ & $0.50 \pm 0.01$ & $0.51 \pm 0.02$ & $0.40 \pm 0.01$ \\
\hline Oxalates & $0.12 \pm 0.00$ & $0.13 \pm 0.00$ & $0.16 \pm 0.01$ & $0.14 \pm 0.00$ & $0.18 \pm 0.00$ & $0.17 \pm 0.00$ & $0.16 \pm 0.02^{0}$ & $0.11 \pm 0.00$ \\
\hline
\end{tabular}

1: 'Kati' produced with Lactobacillus casei, 2: 'Kati' produced with Lactobacillus salivarius,

3: 'Kati' produced with Lactobacillus jensenii, 4: Kati' produced with Lactobacillus cellobiosus,

5: 'Kati' produced with Lactobacillus plantarum, 6: 'Kati' produced with Lactobacillus delbrueckii,

7: 'Kati' produced with Lactobacillus fermentum and 8: 'Kati' purchased as control

Table 7. Sensory evaluation of 'Kati' produced form mixture of white and red sorghum

\begin{tabular}{|l|c|c|c|c|c|c|c|c|}
\hline $\begin{array}{l}\text { Sensory } \\
\text { properties }\end{array}$ & $\mathbf{1}$ & $\mathbf{2}$ & $\mathbf{3}$ & $\mathbf{4}$ & $\mathbf{5}$ & $\mathbf{6}$ & $\mathbf{7}$ & $\mathbf{8}$ \\
\hline Taste & $6.97^{\mathrm{c}} \pm 0.85$ & $7.50^{\mathrm{b}} \pm 0.90$ & $5.65^{\mathrm{d}} \pm 2.00$ & $6.87^{\mathrm{c}} \pm 0.57$ & $8.69^{\mathrm{a}} \pm 2.0$ & $6.80^{\mathrm{c}} \pm 0.76$ & $7.69^{\mathrm{b}} \pm 2.00$ & $8.37^{\mathrm{a}} \pm 0.72$ \\
\hline Colour & $6.80^{\mathrm{c}} \pm 0.76$ & $7.20^{\mathrm{b}} \pm 0.66$ & $6.97^{\mathrm{c}} \pm 0.76$ & $7.62^{\mathrm{b}} \pm 2.00$ & $8.59^{\mathrm{a}} \pm 2.00$ & $7.10^{\mathrm{bc}} \pm 1.10$ & $8.10^{\mathrm{a}} \pm 0.70$ & $7.03^{\mathrm{b}} \pm 0.60$ \\
\hline Texture & $6.62^{\mathrm{b}} \pm 2.00$ & $8.31^{\mathrm{a}} \pm 2.00$ & $6.97^{\mathrm{b}} \pm 0.89$ & $6.90^{\mathrm{b}} \pm 1.20$ & $8.00^{\mathrm{a}} \pm 0.70$ & $7.13^{\mathrm{b}} \pm 0.97$ & $7.19^{\mathrm{b}} \pm 2.00$ & $7.20^{\mathrm{b}} \pm 0.76$ \\
\hline Aroma & $7.10^{\mathrm{b}} \pm 0.76$ & $7.50^{\mathrm{b}} \pm 0.90$ & $6.90^{\mathrm{bc}} \pm 1.20$ & $7.10^{\mathrm{b}} \pm 1.10$ & $8.10^{\mathrm{a}} \pm 071$ & $7.23^{\mathrm{b}} \pm 0.69$ & $7.53^{\mathrm{b}} \pm 0.94$ & $8.73^{\mathrm{a}} \pm 2.00$ \\
\hline $\begin{array}{l}\text { Overall } \\
\text { acceptance }\end{array}$ & $6.87^{\mathrm{c}} \pm 0.68$ & $7.63^{\mathrm{ab}} \pm 0.71$ & $6.63^{\mathrm{c}} \pm 2.00$ & $7.13^{\mathrm{b}} \pm 0.57$ & $8.35^{\mathrm{a}} \pm 0.50$ & $7.07^{\mathrm{b}} \pm 0.78$ & $7.58^{\mathrm{ab}} \pm 2.00$ & $7.83^{\mathrm{a}} \pm 2.00$ \\
\hline
\end{tabular}

Values followed by the same superscript in a row is not significantly different at $P \geq 0.05$

1: 'Kati' produced with Lactobacillus casei, 2: 'Kati' produced with Lactobacillus salivarius,

3: 'Kati' produced with Lactobacillus jensenii, 4: 'Kati' produced with Lactobacillus cellobiosus,

5: 'Kati' produced with Lactobacillus plantarum, 6: 'Kati' produced with Lactobacillus delbrueckii,

7: 'Kati' produced with Lactobacillus fermentum and 8: 'Kati' purchased as control. 


\section{Conclusions}

Starter cultures in 'Kati' will serve as probiotics, which are live microorganisms and when consumed in adequate amounts could confer health benefits on the host. Fermented foods containing $\mathrm{LAB}$ can be attributed to the presence of some essential nutrients and bioactive compounds that have potential to improve human health.

\section{References}

Abegaz, K. (2007). Isolation, characterization and identification of lactic acid bacteria involved in traditional fermentation of Borde, an Ethiopian cereal beverage. African Journal of Bacteriology 6(12), 1469-1478.

Achi, O.K., Asamudo, N.U. (2019). Cerealbased fermented foods of Africa as functional foods. In; Mérillon JM., Ramawat K. (eds) Bioactive molecules in food. Phytochemistry. Springer, Cham.

Adesulu, A. T., Awojobi, K. O. (2014). Enhancing sustainable development through indigenous fermented food products in Nigeria. African Journal of Microbiology Research 8(12),1338-1343.

Adeyemo, S.M., Onilude, A.A. (2013). Enzymatic reduction of anti-nutritional factors in fermenting soybeans by Lactobacillus plantarum isolates from fermenting cereals. Nigerian Food Journal, 31(2), 84-90

Adimpong, B., Nielsen, D. S., Sørensen, K. I., Derkx, P. M. F., Jespersen L. (2012). Genotypic characterization and safety assessment of lactic acid bacteria from indigenous African fermented products. BMC Microbiology, 12, 75-89.

Admassie, M. (2018). A review on food fermentation and the biotechnology of lactic acid bacteria. World Journal of Food Science and Technology, 2(1), 19-24.

Ali, A.A., Mustafa, M.M. (2009). Isolation, characterization and identification of lactic acid bacteria from fermented sorghum dough used in
Sudanese 'Kisra' preparation. Pakistan Journal of Nutrition, 8, 1814-1818.

Anal, A. K. (2019). Quality ingredients and safety concerns for traditional fermented foods and beverages from Asia: a review. Fermentation 2019, 5(1), 8; https://doi.org/10.3390/fermentation501000 $\underline{8}$.

AOAC Association of Official Analytical Chemists (1990). Association of Official Analytical Chemists. Official Methods of Analysis 15th Edition (Helrick, K.ed.). AOAC, Arlington, Virginia.

Assohoun, M. C. N., Djeni, T. N., KoussémonCamara, M., Brou, K. (2013). Effect of fermentation process on nutritional composition and Aflatoxins concentration of 'Doklu', a fermented maize based food. Food and Nutrition Sciences, 4, 11201127.

Blandino, A., Al-Aseeri, M. E., Pandiella, S. S., Cantero, D., Webb, C. (2003) Cereal-based fermented foods and beverages. Food Research International, doi; 10.1016/s09639969(03)00009-7.

Campbell-Platt, G. (1994). Fermented foods- a world perspective. Food Research International 27, 253.

Cappuccino, G.J. and Sherman, N. 1999. Microbiology, A laboratory manual; Biochemical activities of microorganism, fifth ed. Benjamin/Cumming science Publishing, California

Chelule, P.K., Mbongwa, H.P., Carries, S., Gqaleni, N. (2010). Lactic acid fermentation improves the quality of a 'Mahewu', a traditional South African maize-based porridge. Food Chemistry, 122(3), 656-661.

De Vuyst, L., Vandamme, E.J. (1994). Bacteriocins of lactic acid bacteria; Microbiology, genetics and applications. London; Blackie Academic and Professional.

Delwiche, J. (2009) Psychological considerations in sensory analysis. In Clark, S., Costello, M., Drake, M., Body-felt, F. 
(eds). The sensory evaluation of dairy products. Springer.

Dimidi, E., Cox, S. R., Rossi, M., Whelan, K. (2019). Fermented foods: definitions and characteristics, impact on the gut microbiota and effects on gastrointestinal health and disease. Nutrients 11, 1806; doi:10.3390/nu11081806

Egwim, E., Amanabo, M., Yahaya A, Bello M. (2013). Nigerian indigenous fermented foods; processes and prospects. In; Makun HA, editor. Mycotoxins and food safety in developing countries. Croatia; Intech. 1096. doi; $10.5772 / 5287$.

Gobbetti, M., Corsetti, A., Rossi, J. (1994). The sourdough microflora. Interactions between lactic acid bacteria and yeasts; Metabolism of carbohydrates. Applied Microbiology Biotechnology, 41; 456-460.

Hasan, M. N., Sultan, M. Z., Mar-E-Um, M. (2014). Significance of fermented food in nutrition and food science. Journal of Scientific Research, 6(2), 373-386.

Holzapfel, W. H. (1997). Use of starter cultures in fermentation on a household scale. Food Control, 8, 241-258.

Justé, A., Malfliet, S., Lenaerts, M., de Cooman, L., Aerts, G., Willems, K. A., Lievens, B. (2011). Microflora during malting of barley; overview and impact on malt quality. Brewing Science, 64,22-32

Krieg, N.R., Staley, J.T., Brown, D.R., Hedlund, B.P., Paster, B.J., Ward, N.L., Ludwig, W., Whitman, W.B. (2010). The Bacteroidetes, Spirochaetes, Tenericutes (Mollicutes), Acidobacteria, Fibrobacteres, Fusobacteria, Dictyoglomi, Gemmatimonadetes, Lentisphaerae, Verrucomicrobia, Chlamydiae, and Planctomycetes, second ed. (volume 4). DOI; 10.1007/978-0-38768572-4. Springer New York Dordrecht Heidelberg London.

Krishna, G., S. K. Ranahan. (1980). Laboratory manual for nutrition research. Vikas Publishing House PVT Ltd., Ghaziabad, Indian.

Kumari, S., Guleria, P., Dangi, N. (2015). Cereal Based Beverages and Fermented Foods; A
Review. International Journal of Enhanced Research in Science, Technology \& Engineering, 4(10), 2319-7463.

Lafiandra, D., Riccardi G., Shewry P. R. (2014). Improving cereal grain carbohydrates for diet and health. Journal of Cereal Sciences 59;312-326.

Makkar, H.P.S., Goodchild, A.V. (1996). Quantification of tannins; a laboratory manual. International Center of Agricultural Research in Dry Areas, Aleppo. 4

Meilgaard, M., Civile, G. V., Carr, B.T. (2007). Sensory evaluation techniques. 4th ed. Boca Raton, FL; CRC Press.

Mora-Villalobos, J.A., Montero-Zamora, J., Barboza, N., Rojas-Garbanzo, C., Usaga, J., Redondo-Solano, M., Schroedter, L., Olszewska-Widdrat, A., López-Gómez, J.P. (2020). Multi-product lactic acid bacteria fermentations: a review. Fermentation, 6, 23.

Mukisa, I. M., Ntaate, D., Byakika, S. (2016). Application of starter cultures in the production of Enturire - a traditional sorghum-based alcoholic beverage. Food Science and Nutrition, 5(3), 609-616.

Obadina, A.O. Akinola O.J., Shittu, T.A., Bakare, H.A. (2013). Effect of natural fermentation on the chemical and nutritional composition of fermented Soymilk Nono. Nigerian Food Journal, 31(2), 91-97.

Omemu, A. M., Okafor, U. I., Obadina, A. O., Bankole, M. O., Adeyeye, S. A. O. (2018). Microbiological assessment of maize 'Ogi' co-fermented with pigeon pea. Food Science and Nutrition, 6(5),1238-1253.

Ogodo, A.C., Ugbogu, O.C., Onyeagba, R.A., Okereke, H. C. (2019). Microbiological quality, proximate composition and in vitro starch/protein digestibility of Sorghum bicolor flour fermented with lactic acid bacteria consortia. Chemical and Biological Technologies in Agriculture 6,7. https://doi.org/10.1186/s40538-019-0145-4.

Oguntoyinbo, F. A., Narbad, A. (2012). Molecular characterization of lactic acid bacteria and in situ amylase expression 
during traditional fermentation of cereal foods. Food Microbiology, 31(2), 254-262.

Okeke, C. A., Ezekiel, C. N., Nwangburuka, C. C., Sulyok, M., Ezeamagu, C. O., Adeleke, R. A., Dike, S.K., Krska, R. (2015). Bacterial diversity and mycotoxin reduction during maize fermentation (steeping) for 'Ogi' production. Frontiers in Microbiology, 6, 1402.

Samson, R.A., Houbraken, J., Thrane, U., Frisvad, J.C., Andersen, B. (2010). Fungi and indoor fungi, CBS laboratory Manual Series. CBS-KNAW Fungal Biodiversity Centre, Utrecht, The Netherlands.

Sandhu, K. S., Punia, S., Kaur M. (2017). Fermentation of cereals; a tool to enhance bioactive compounds. In Gahlawat S., Salar R., Siwach P., Duhan J., Kumar S., Kaur P. (eds), Plant biotechnology: recent advancements and developments. Springer Nature, Singapore.

Şanlier, N., Gökcen, B.B., Sezgin, A.C. (2019). Health benefits of fermented foods. Critical Review in Food Science and Nutrition, 59(3), 506-527.

Soro-Yao, A.A., Brou, K., Amani, G., Thonart, P., Djè, K. M. (2014). The use of lactic acid bacteria starter cultures during the processing of fermented cereal-based foods in West Africa; a review. Tropical Life Sciences Research, 25(2), 81-100

Steinkraus, K., 1996. Handbook of Indigenous Fermented Foods. Marcel Dekker Inc., New York, USA.

Van-Nierop, S.N.E, Rautenbach, M., Axcell, B.C., Cantrell, I. C. (2006). The impact of microorganisms on barley and malt quality - a review. Journal of the American Society of Brewing Chemists, 64(2), 69-78

Yang, J., Lee, J. (2019). Application of sensory descriptive analysis and consumer studies to investigate traditional and authentic foods; a review. Foods, 8, 54-65. 